\title{
Bidragydere
}

\section{Robert Andersson}

Født 1968, docent i kriminologi, Linnéuniversitetet i Växjö.

\section{Jørgen Bruhn}

Født 1968, docent i litteraturvidenskab, Linnéuniversitetet i Växjö.

\section{Johanne Helbo Bøndergaard}

Født 1983, ph.d.-studerende i litteraturhistorie, Institut for Æstetik og Kommunikation, Aarhus Universitet.

\section{Lasse Gammelgaard}

Født 1983, ph.d.-studerende i nordisk sprog og litteratur, Institut for Æstetik og Kommunikation, Aarhus Universitet.

\section{Anne Gjelsvik}

Født 1965, professor i filmvidenskab, Institutt for kunst og medievitenskap, Norges teknisk-naturvitenskaplige universitet, Trondheim.

\section{W.J.T. Mitchell}

Født 1942, professor i engelsk og kunsthistorie, University of Chicago.

\section{Jakob Isak Nielsen}

Født 1975, lektor i medievidenskab, Institut for Æstetik og Kommunikation, Aarhus Universitet.

\section{Jan Løhmann Stephensen}

Født 1972, postdoc i æstetik og kultur, Institut for Æstetik og Kommunikation, Aarhus Universitet.

\section{Sara Tanderup}

Født 1986, ph.d.-studerende i litteraturhistorie, Institut for Æstetik og Kommunikation, Aarhus Universitet.

\section{Thomas Thorhauge}

Født 1973, tegneserietegner for Politiken. Har udgivet Kom Hjem (Rosinante 2009) og Det sidste ord (Rosinante 2012). Formand for Dansk Tegneserieråd. 